\title{
Seasonal Dynamics of Soil Microbial Biomass Carbon (SMBC) in Different Land Uses in Ri-Bhoi District of Meghalaya, India
}

\author{
Euwanrida Adleen Shylla Lyngdoh ${ }^{1 *}$ and R.M. Karmakar ${ }^{2}$ \\ ${ }^{1}$ School of Natural Resource Management, College of Post-Graduate Studies, CAU (I), \\ Umiam, Meghalaya, India \\ ${ }^{2}$ Department (Soil Science), Assam Agricultural University, Assam, India \\ *Corresponding author
}

\begin{tabular}{|l|}
\hline K e y w o r d s \\
$\begin{array}{l}\text { Soil microbial biomass } \\
\text { carbon, Seasonal } \\
\text { dynamics, Depth } \\
\text { variation, Land use } \\
\text { variation }\end{array}$ \\
\hline Article Info \\
\hline $\begin{array}{l}\text { Accepted: } \\
\text { 30 January } 2018 \\
\text { Available Online: } \\
\text { 10 March } 2018\end{array}$ \\
\hline
\end{tabular}

\section{Introduction}

Soil organic matter is an important component of soil quality and productivity; however, its measurement alone does not adequately reflect changes in soil quality and nutrient status (Franzluebbers et al., 1995; Bezdicek et al., 1996) Microbial biomass, which represents an important labile pool of nutrients in soil (Henrot and Robertson, 1994), plays a significant role in nutrient transformation and conservation processes. The importance of
Seasonal variations in microbial biomass carbon and its relationship with some soil parameters were studied in Ri-Bhoi District of Meghalaya. Soil samples were drawn from the soil horizons of three land uses (Table A) in pre-monsoon, monsoon and post-monsoon seasons. The SMBC in all the land uses decreased significantly with depth however SMBC is found to be different from one land use to another. SMBC differs from one season to another and seasonal variation was significant as SMBC attained its peak in monsoon season. In case of soil physico-chemical parameters, organic carbon, available N, P, K showed significant depth-variation. The soil texture varied from sandy to clayey. The soils varied widely in OC (0.39-1.20 percent), bulk density (0.97-1.67 gm/cc), pH (4.5-5.4), base saturation (18.1-50.9 percent) and available $\mathrm{N}\left(501.8-715.0 \mathrm{~kg} \mathrm{ha}^{-1}\right), \mathrm{P}_{2} \mathrm{O}_{5}(9.8-32.1$ $\left.\mathrm{kg} \mathrm{ha}^{-1}\right), \mathrm{K}_{2} \mathrm{O}\left(241.9-392.3 \mathrm{~kg} \mathrm{ha}^{-1}\right)$. The bacterial and fungal population ranged from 44$236 \mathrm{cfu} \times 10^{6}$ and $2.90-25.55 \mathrm{cfu} \times 10^{2}$ per gram soil, respectively. The SMBC was observed to be the highest under forest vegetation and was the lowest in agricultural cropland. In the present study, wide variations were observed in SMBC which were related to seasonal variation and varied land uses. 
tool for understanding and predicting longterm effects on changes in land use and associated soil conditions (Sharma et al., 2004). Many factors such as temperature, moisture content, clay content and $\mathrm{pH}$ are known to affect microbial biomass in soil (Carter, 1986; Kaiser et al., 1992; Gestel et al., 1993; Nicojardot et al., 1994). A marked seasonal cycle of microbial biomass has been reported for both tropical and temperate forest soils (Singh et al., 1989; Diaz-Ravina et al., 1995). Whereas Ross et al., (1981) reported large annual fluctuations in soil microbial biomass, Patra et al., (1990) observed only small annual changes. A few recent studies (Srivastava and Singh, 1991; Diaz-Ravina et al., 1995) have highlighted the influence of land use and soil physico-chemical properties on microbial biomass. In many instances, the disturbed areas are allowed to undergo natural recovery of vegetation for 5 to 20 years depending on population pressure and land availability. Study of microbial biomass in soil along a chronosequence of vegetation regrowth in these disturbed sites may give insights into the role of microbes in restoring soil fertility during secondary succession. The scarcity of available data indicating the effects of land use change on soil microbial $\mathrm{C}$ led us to assess the impact of these changes for forest, pasture, and agricultural lands in the two districts of Meghalaya. The second objective of this study was to establish relationships between microbial biomass $\mathrm{C}$ and the physico-chemical characteristics of the soil, such as texture, organic $\mathrm{C}, \mathrm{pH}$ under the same ecological conditions.

\section{Materials and Methods}

\section{Study area}

Ri-Bhoi district of Meghalaya was selected for the present study. Ri-Bhoi district lies between $25^{\circ} 15^{\prime}$ and $26^{\circ} 15^{\prime} \mathrm{N}$ latitudes and $91^{\circ} 45^{\prime}$, and $92^{\circ} 15^{\prime}$ E longitudes (Fig. 1). It is bounded on the north by Kamrup district and on the East by Jaintia Hills and Karbi Anglong district of Assam and on the West by West Khasi Hills district. Ri-Bhoi district covers an area of $2448 \mathrm{~km}^{2}$. The sampling sites differ in aspect of vegetation, elevation, rainfall and temperature. The Ri-Bhoi district of Meghalaya consists mainly of Archeangnessic complex, Shillong Group of rocks-quartzites, granites and alluvium. In Ri-Bhoi district the average annual rainfall is $2,695 \mathrm{~mm}$. The soil moisture regime of the study area is udic. The temperature of these sites ranges from $10^{\circ} \mathrm{C}$ in December to $30^{\circ} \mathrm{C}$ in the month of July and August. Normally January and August months records minimum $\left(12.3^{\circ} \mathrm{C}\right)$ and maximum $\left(35.2^{\circ} \mathrm{C}\right)$ temperatures respectively. The temperature regime of the study area is thermic. The State as a whole is rich in species of flora and varies from open scrub (Grassland) to pine forest in the central plateau region. The rest is covered by mostly deciduous to evergreen forests and transitional tropical moist deciduous pine forests.

\section{Sample collection}

Three soil profiles, from Ri-Bhoi district B1, B2 and B3 were collected from areas under agricultural crop, tea, and forest, the detailed description of these profiles are presented in Table 1. Horizon-wise soil samples were collected from each profile to study the variation of soil microbial biomass carbon depth wise. On the other hand samples were collected from each site for three seasons pre monsoon (March to May), Monsoon (June to September) and post monsoon (October to February). Samples were taken from each horizon of each profile to study its seasonal variation.

\section{Analytical procedures}

The soil samples were air dried, ground and passed through a $2 \mathrm{~mm}$ sieve. The sieved soil 
samples were stored in polythene bags and subsequently used for various physicochemical analyses. Fresh soil samples were stored in refrigerator for microbiological analyses.

MBC was determined by chloroform fumigation-extraction technique following the method of Vance et al., (1987). Fresh soil samples $(5 \mathrm{gm})$ in $50 \mathrm{~mL}$ glass beakers were placed in a desiccator with a vial of soda lime. Another beaker containing $50 \mathrm{~mL}$ ethanol free $\mathrm{CHCl}_{3}$ was placed in the same desiccator and it was evacuated until the $\mathrm{CHCl}_{3}$ has boiled vigorously for $2 \mathrm{~min}$. The desiccator was then incubated in dark at $25{ }^{\circ} \mathrm{C}$ for $24 \mathrm{~h}$. After fumigation, $\mathrm{CHCl}_{3}$ was removed by repeated evacuation; the soil samples were then extracted with $25 \mathrm{~mL} 0.5 \mathrm{M} \mathrm{K}_{2} \mathrm{SO}_{4}$ (5:1) for 30 min by oscillating shaking at $200 \mathrm{rpm}$ and then filtered through a Whatman No. 42 filter paper.

Organic carbon content in the extracts was measured with dichromate $(66.7 \mathrm{mM})$ digestion method. To $8 \mathrm{ml}$ of extract in a 250 $\mathrm{ml}$ conical flask, $2 \mathrm{ml}$ of $\mathrm{K}_{2} \mathrm{Cr}_{2} \mathrm{O}_{7}(66.7 \mathrm{mM})$ and $15 \mathrm{ml}$ of the digestion mixture (2:1 conc. $\mathrm{H}_{2} \mathrm{SO}_{4}: \mathrm{H}_{3} \mathrm{PO}_{4}$ (v/v) was added. The mixture was gently refluxed for $30 \mathrm{~min}$, allowed to cool and diluted with $20 \mathrm{ml}$ distilled water. The excess $\mathrm{K}_{2} \mathrm{Cr}_{2} \mathrm{O}_{7}$ was measured by back titration with ferrous ammonium sulphate (40.0mM) using 1.10-phenanthroline-ferrous sulphate complex $(25 \mathrm{mM})$ solution as indicator. $\mathrm{MBC}$ was calculated from the differences in extractable organic carbon (OC) between the fumigated and non-fumigated soil sample and expressed as $\mu \mathrm{g} / \mathrm{g}$ on dry weight basis as

\section{$\operatorname{MBC}(\mu \mathrm{g} / \mathrm{g})=\mathrm{Ec} / \mathrm{k}_{\mathrm{EC}}$}

Where $\mathrm{Ec}=((\mathrm{OC}$ extracted from fumigated soil) - (OC extracted from non-fumigated soil) and $\mathrm{k}_{\mathrm{EC}}=0.38$ (Vance et al., 1987).
Soil $\mathrm{pH}$ was determined with $\mathrm{pH}$ meter in 1:25 soil: water suspension. The particle size analysis was carried out by pipette method after removing organic matter (Piper, 1966). Bulk density of the soil was determined by clod method (Black, 1965), organic C by titrimetric method (Walkley and Black, 1934), available $\mathrm{N}$ content by alkaline permanganate method (Subbiah and Asija, 1956), whereas available $\mathrm{P}$ was extracted by Bray I reagent (Bray and Kurtz 1945) and determined by blue color method. Available K was extracted by neutral normal ammonium acetate and estimated with the help of flame photometer as described by Jackson (1973). For mechanical analysis international pipette method was followed. Data obtained for different aspects were subjected to standard statistical treatment.

\section{Results and Discussion}

\section{Physico-chemical parameters}

Soil varied from sandy to clayey and the structure varied from crumb to sub-angular blocky. Weak structure was observed in the surface and subsurface horizons. The bulk density was low in the surface horizon and it increased with soil depth. Lower bulk density in the surface horizon may be due to higher organic carbon content in the surface. The bulk density of the soils was found to be inversely related with soil organic carbon as evident from the negative significant correlation between bulk density and organic carbon $(\mathrm{r}=-0.689 * *)$ (Table 5).

The $\mathrm{pH}$ (1:2.5 soil: water ratio) of the soils was found to be in acidic range (Table 3 ) varying widely from 4.5 to 5.4. Higher $\mathrm{pH}$ was observed in $\mathrm{B} 3$ ( $\mathrm{pH}$ 5.0-5.4) under forest land which may be due to less weathering and/or water saturation in some parts of the year. The significant negative correlations of soil $\mathrm{pH}$ with clay $(\mathrm{r}=-0.572 * *)$ (Table 5) 
suggest that clay is the main contributor to soil acidity. Higher concentration of nutrient elements like $\mathrm{N}, \mathrm{P}, \mathrm{K}$ and organic $\mathrm{C}$ were found in surface soils which generally decreases with increase in soil depth due to decomposition of weeds and pruned materials and also regular application of FYM and fertilizers. The available nitrogen content was higher in the surface horizons and it decreased with soil depth except in some horizons where its distribution was irregular. Irregular distribution of available $\mathrm{N}$ in soils (B2) (Table 3) may be attributed to leaching of $\mathrm{N}$ to lower horizons during cultivation horticultural crops respectively. Significant positive correlation of available $\mathrm{N}$ with soil organic carbon $(\mathrm{r}=$ $0.573 * *$ ) indicates that soil organic carbon is a good indicator of available $\mathrm{N}$ in the soil; on the other hand, negative correlation with $\mathrm{pH}$ $\left(\mathrm{r}=-0.546^{* *}\right)$ indicates that soil acidity retards loss of available $\mathrm{N}$ in soil resulting in more accumulation in soil. The available $\mathrm{P}_{2} \mathrm{O}_{5}$ content of the soils was higher in the surface horizon and it decreased soil depth (Table 3). In general, available $\mathrm{P}_{2} \mathrm{O}_{5}$ rated medium to high in the studied soils. Significant positive correlations of available $\mathrm{P}_{2} \mathrm{O}_{5}$ with soil organic carbon $(\mathrm{r}=0.724 * *)$ and negative correlation with $\mathrm{pH}(\mathrm{r}=-0.220)$ (Table 5) suggest contribution of soil organic carbon and soil acidity to available form of $\mathrm{P}_{2} \mathrm{O}_{5}$. The available $\mathrm{K}_{2} \mathrm{O}$ content of the soil was high. Higher amount of available $\mathrm{N}, \mathrm{P}_{2} \mathrm{O}_{5}$ and $\mathrm{K}_{2} \mathrm{O}$ in the surface horizons might be due to phytocycling of these nutrient elements.

\section{Microbial biomass parameter}

\section{Depth Dynamics in different land use}

The amount of microbial biomass carbon (MBC) (Table 6) was observed to be the highest in the upper one or two horizons in the district and it decreased with soil depth in the monsoon season as compared to the premonsoon and post-monsoon seasons. The
MBC was also found to differ in different land use type, These differences in the microbial biomass $\mathrm{C}$ may be due to the climatic conditions, differences in ground cover vegetation, the number of roots, soil types and properties, types of land use and management, as well as variations in sampling times (Anderson and Domsch, 1989; Priha, 1999; Murrieta et al., 2007).

The highest amount of microbial biomass carbon (MBC) has been observed in the forest soils (B3) in the monsoon season. The relatively dense structure of plants and a greater accumulation of litter and fine roots in the understorey of forest and pasture may favour the growth of microbial populations and the accumulation of $\mathrm{C}$ in microbial biomass.

\section{Seasonal dynamics}

The amount of microbial biomass carbon (MBC) (Table 6) was observed to be the highest in the monsoon season as compared to the pre-monsoon and post-monsoon seasons. Low ambient and soil temperatures in winter months lead to lower mirobial activity leading to low MBC during post-monsoon season (Mithani et al., 1996).

Peak microbial biomass during monsoon season when the air and soil temperatures are high indicates a period of high microbial activity and thus resulting in greater values of MBC. It is well known that soil organic C strongly affects the amount and activity of soil microbial biomass (Diaz-Ravina et al., 1988; Jenkinson, 1988). The MBC was related to soil organic carbon as evident from significant positive correlation between the two during pre-monsoon $\quad\left(\mathrm{r}=0.871^{* *}\right)$, monsoon $(\mathrm{r}=0.664 * *)$ and post-monsoon $(\mathrm{r}=0.507 * *)$ (Table 7). On the other hand, negative correlation between $\mathrm{MBC}$ and soil $\mathrm{pH}$ (Table 7) indicates influence of soil acidity on MBC. 
Table.1 Site characteristics of the study area

\begin{tabular}{|c|c|c|c|c|c|c|}
\hline $\begin{array}{l}\text { Sl. } \\
\text { No. }\end{array}$ & Location & $\begin{array}{c}\text { Latitude } \\
\text { and Longitude }\end{array}$ & Lithology & Physiography & Land use & Slope \\
\hline \multicolumn{7}{|c|}{ Ri-Bhoi District } \\
\hline B1 & Umbih & $\begin{array}{c}25^{\circ} 44.467^{\prime} \mathrm{N} \\
92^{\circ} 01.605^{\prime} \mathrm{E}\end{array}$ & Alluvium & $\begin{array}{c}\text { Intermontane } \\
\text { Valley }\end{array}$ & Agricultural land & $0-1$ \\
\hline B2 & Umeit & $\begin{array}{l}25^{\circ} 42.712^{\prime} \mathrm{N} \\
91^{\circ} 57.366^{\prime} \mathrm{E}\end{array}$ & Alluvium & $\begin{array}{l}\text { Intermontane } \\
\text { Valley }\end{array}$ & $\begin{array}{l}\text { Horticultural land- } \\
\text { vegetable cultivation }\end{array}$ & $0-1$ \\
\hline B3 & $\begin{array}{c}\text { Umiam } \\
\text { (Barapani) }\end{array}$ & $\begin{array}{l}25^{\circ} 40.312^{\prime} \mathrm{N} \\
91^{\circ} 54.273 \mathrm{E}\end{array}$ & Gneiss & Hills & Forest & $3-5$ \\
\hline
\end{tabular}

Table.2 Mechanical composition of the soils of Ri-Bhoi district

\begin{tabular}{|c|c|c|c|c|c|c|}
\hline \multirow[t]{3}{*}{ Horizon } & \multirow[t]{3}{*}{$\begin{array}{c}\text { Depth } \\
\text { (cm) }\end{array}$} & \multirow{2}{*}{\multicolumn{3}{|c|}{$\begin{array}{c}\text { Particle size distribution } \\
\text { (Particle size in mm, soil separates in \%) } \\
\text { Total }\end{array}$}} & \multirow[t]{3}{*}{ Sand / Silt } & \multirow[t]{3}{*}{ Silt / Silt+clay } \\
\hline & & & & & & \\
\hline & & $\begin{array}{c}\text { Sand } \\
(2-0.05)\end{array}$ & $\begin{array}{c}\text { Silt } \\
(0.05-0.002)\end{array}$ & $\underset{(<0.002)}{\text { Clay }}$ & & \\
\hline \multicolumn{7}{|c|}{ B1: Mynsain (Agril crop) } \\
\hline Ap & $0-20$ & 56.6 & 22.5 & 20.9 & 2.52 & 0.52 \\
\hline Bw1 & $20-35$ & 50.8 & 29.5 & 19.7 & 1.72 & 0.60 \\
\hline Bw2 & $35-60$ & 46.6 & 32.6 & 20.8 & 1.43 & 0.61 \\
\hline Bw3 & $60-75$ & 53.0 & 25.7 & 21.3 & 2.06 & 0.55 \\
\hline $\mathbf{C}$ & $75-150$ & 73.8 & 13.7 & 12.5 & 5.34 & 0.52 \\
\hline \multicolumn{7}{|c|}{ B2 : Umeit (Horticulture farm) } \\
\hline Ap & $0-15$ & 19.3 & 46.5 & 34.2 & 0.42 & 0.57 \\
\hline $\mathbf{A B}$ & $15-35$ & 29.7 & 35.9 & 34.5 & 0.83 & 0.52 \\
\hline Bw1 & $35-85$ & 44.2 & 26.1 & 29.7 & 1.69 & 0.48 \\
\hline Bw2 & $85-120$ & 49.7 & 26.5 & 23.7 & 1.88 & 0.72 \\
\hline $\mathbf{C}$ & $120-180$ & 60.7 & 18.2 & 21.1 & 3.34 & 0.47 \\
\hline \multicolumn{7}{|c|}{ B3 :Barapani / Umiam (Forest) } \\
\hline $\mathbf{A}$ & $0-20$ & 79.0 & 9.1 & 11.9 & 8.68 & 0.45 \\
\hline Bw1 & $20-45$ & 60.9 & 11.8 & 27.3 & 5.16 & 0.31 \\
\hline Bw2 & $45-85$ & 61.7 & 9.8 & 28.5 & 6.30 & 0.45 \\
\hline Bw3 & $85-115$ & 58.2 & 13.6 & 28.2 & 4.28 & 0.25 \\
\hline $\mathbf{C}$ & $115-130$ & 72.1 & 13.4 & 14.6 & 5.38 & 0.49 \\
\hline
\end{tabular}


Table.3 Organic carbon, bulk density, $\mathrm{pH}, \mathrm{EC}$ and available nitrogen, potash and phosphorus of the soils of Ri-Bhoi district

\begin{tabular}{|c|c|c|c|c|c|c|c|}
\hline \multirow[t]{2}{*}{ Depth (cm) } & \multirow{2}{*}{$\begin{array}{l}\text { O.C. } \\
(\%)\end{array}$} & \multirow{2}{*}{$\begin{array}{c}\text { Bulk density } \\
\text { g/cc }\end{array}$} & \multirow{2}{*}{$\begin{array}{c}\mathrm{pH} \\
\left(1: 2.5 \mathrm{H}_{2} \mathrm{O}\right)\end{array}$} & \multirow{2}{*}{$\begin{array}{c}\text { E.C. } \\
\left(1: 2.5 \mathrm{H}_{2} \mathrm{O}\right) \\
\left(\mathrm{dSm}^{-}\right.\end{array}$} & \multicolumn{3}{|c|}{ Available (kg ha $\left.{ }^{-1}\right)$} \\
\hline & & & & & $\mathbf{N}$ & $\mathbf{P}_{2} \mathbf{O}_{5}$ & $\mathbf{K}_{2} \mathbf{O}$ \\
\hline \multicolumn{8}{|c|}{ B1: Mynsain (Agril crop) } \\
\hline $0-20$ & 0.96 & 1.08 & 5.0 & 0.06 & 589.6 & 27.2 & 310.7 \\
\hline $20-35$ & 0.77 & 1.11 & 5.2 & 0.06 & 564.5 & 22.4 & 307.1 \\
\hline $35-60$ & 0.53 & 1.10 & 4.5 & 0.08 & 577.0 & 13.5 & 305.0 \\
\hline $60-75$ & 0.48 & 1.22 & 4.7 & 0.08 & 564.5 & 10.9 & 282.5 \\
\hline $75-150$ & 0.39 & 1.41 & 5.1 & 0.07 & 526.8 & 10.6 & 308.2 \\
\hline \multicolumn{8}{|c|}{ B:2 Umeit (Horticulture farm) } \\
\hline $0-15$ & 1.03 & 1.11 & 5.1 & 0.06 & 715.0 & 32.1 & 392.3 \\
\hline $15-35$ & 0.91 & 1.27 & 5.2 & 0.05 & 689.9 & 20.8 & 317.9 \\
\hline $35-85$ & 0.62 & 1.38 & 5.1 & 0.05 & 539.4 & 15.9 & 241.9 \\
\hline $85-120$ & 0.42 & 1.55 & 5.3 & 0.06 & 501.8 & 12.0 & 284.9 \\
\hline $120-180$ & 0.40 & 1.67 & 5.2 & 0.06 & 514.3 & 10.4 & 318.5 \\
\hline \multicolumn{8}{|c|}{ B3 : Barapani / Umiam (Forest) } \\
\hline $0-20$ & 1.20 & 0.97 & 5.2 & 0.07 & 715.0 & 16.3 & 397.2 \\
\hline $20-45$ & 0.81 & 0.97 & 5.2 & 0.07 & 627.2 & 15.9 & 326.2 \\
\hline $45-85$ & 0.77 & 1.15 & 5.4 & 0.05 & 664.8 & 10.3 & 298.1 \\
\hline $85-115$ & 0.62 & 1.33 & 5.4 & 0.06 & 589.6 & 9.8 & 390.0 \\
\hline 115-130 & 0.50 & 1.47 & 5.0 & 0.07 & 564.6 & 10.1 & 271.6 \\
\hline
\end{tabular}

Table.4 Exchangeable cations, cation exchange capacity (CEC), base saturation and free iron and aluminium oxides in the soils of Ri-Bhoi district

\begin{tabular}{|c|c|c|c|c|c|c|c|c|}
\hline \multirow{2}{*}{$\begin{array}{c}\text { Depth } \\
\text { (cm) }\end{array}$} & \multicolumn{4}{|c|}{ Exchangeable bases } & \multirow[t]{3}{*}{ CEC } & \multirow{2}{*}{$\begin{array}{c}\text { Base } \\
\text { Saturation }\end{array}$} & \multirow[t]{2}{*}{$\mathrm{Fe}_{2} \mathrm{O}_{3}$} & \multirow[t]{2}{*}{$\mathbf{A l}_{2} \mathbf{O}_{3}$} \\
\hline & $\mathrm{Ca}^{++}$ & $\mathrm{Mg}^{++}$ & $\mathbf{K}^{+}$ & $\mathrm{Na}^{+}$ & & & & \\
\hline & \multicolumn{4}{|c|}{ 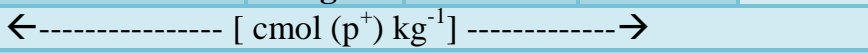 } & & \multicolumn{3}{|c|}{$\leftarrow--\cdot(\%)$} \\
\hline \multicolumn{9}{|c|}{ B1: Mynsain (Agril crop) } \\
\hline 0-20 & 1.63 & 1.25 & 0.15 & 0.79 & 8.15 & 46.9 & 1.80 & 0.42 \\
\hline $20-35$ & 1.75 & 1.20 & 0.17 & 0.78 & 9.23 & 42.3 & 1.80 & 0.62 \\
\hline $35-60$ & 1.50 & 1.10 & 0.16 & 0.78 & 8.69 & 40.7 & 1.74 & 1.04 \\
\hline $60-75$ & 1.25 & 1.00 & 0.18 & 0.72 & 9.78 & 32.2 & 1.86 & 0.68 \\
\hline 75-150 & 1.00 & 0.75 & 0.13 & 0.79 & 7.06 & 37.8 & 1.86 & 0.89 \\
\hline \multicolumn{9}{|c|}{ B2 : Umeit (Horticulture farm) } \\
\hline $0-15$ & 1.70 & 0.50 & 0.11 & 0.73 & 5.97 & 50.9 & 1.82 & 1.29 \\
\hline $15-35$ & 1.50 & 0.50 & 0.18 & 0.81 & 9.78 & 30.6 & 1.80 & 1.51 \\
\hline $35-85$ & 1.70 & 0.50 & 0.20 & 0.62 & 10.86 & 27.8 & 1.86 & 1.17 \\
\hline $85-120$ & 1.35 & 1.25 & 0.19 & 1.00 & 10.32 & 36.8 & 1.84 & 0.89 \\
\hline $120-180$ & 1.20 & 0.05 & 0.21 & 0.81 & 11.41 & 19.9 & 1.90 & 1.40 \\
\hline \multicolumn{9}{|c|}{ B3 :Barapani / Umiam (Forest) } \\
\hline $0-20$ & 1.90 & 0.50 & 0.23 & 1.01 & 12.5 & 29.2 & 1.49 & 1.15 \\
\hline $20-45$ & 1.40 & 0.25 & 0.15 & 0.83 & 8.15 & 32.3 & 1.56 & 1.57 \\
\hline $45-85$ & 1.20 & 0.75 & 0.24 & 0.76 & 13.04 & 22.6 & 1.59 & 1.34 \\
\hline $85-115$ & 1.20 & 0.50 & 0.14 & 1.00 & 7.60 & 37.3 & 1.40 & 1.15 \\
\hline $115-130$ & 1.00 & 0.25 & 0.22 & 0.69 & 11.95 & 18.1 & 1.70 & 1.63 \\
\hline
\end{tabular}


Table.5 Correlation coefficients (r) among soil properties

\begin{tabular}{l|r|r|r|r|r|r|r|r|r|}
\hline & \multicolumn{1}{c|}{ Sand } & \multicolumn{1}{c|}{ Silt } & \multicolumn{1}{c|}{ Clay } & \multicolumn{1}{c|}{$\mathrm{OC}$} & \multicolumn{1}{c}{$\mathrm{BD}$} & \multicolumn{1}{c|}{$\mathrm{pH}$} & \multicolumn{1}{c}{$\mathrm{EC}$} & $\mathrm{Fe}_{2} \mathrm{O}_{3}$ & $\mathrm{Al}_{2} \mathrm{O}_{3}$ \\
\hline Sand & 1.000 & & & & & & & & \\
Silt & -0.853 & 1.000 & & & & & & & \\
Clay & -0.841 & 0.436 & 1.000 & & & & & & \\
$\mathrm{OC}$ & -0.161 & 0.123 & 0.150 & 1.000 & & & & & \\
$\mathrm{BD}$ & -0.240 & 0.133 & 0.277 & -0.689 & 1.000 & & & & \\
$\mathrm{pH}$ & 0.554 & -0.370 & -0.572 & -0.086 & -0.176 & 1.000 & & & \\
$\mathrm{EC}$ & 0.209 & -0.125 & -0.230 & -0.110 & -0.066 & -0.336 & 1.000 & & \\
$\mathrm{~N}$ & -0.425 & 0.225 & 0.500 & 0.573 & -0.132 & -0.557 & 0.155 & & \\
$\mathrm{P}_{2} \mathrm{O}_{5}$ & -0.513 & 0.536 & 0.330 & 0.766 & -0.421 & -0.219 & -0.075 & & \\
$\mathrm{~K}_{2} \mathrm{O}$ & -0.167 & 0.203 & 0.076 & 0.580 & -0.383 & -0.060 & 0.005 & & \\
$\mathrm{Ca}^{++}$ & -0.200 & 0.202 & 0.133 & 0.496 & -0.207 & -0.226 & 0.075 & & \\
$\mathrm{Mg}^{++}$ & -0.193 & 0.150 & 0.175 & 0.086 & -0.181 & -0.567 & 0.056 & & \\
$\mathrm{~K}^{+}$ & -0.252 & 0.008 & 0.425 & 0.191 & 0.139 & -0.614 & -0.111 & & \\
$\mathrm{Na}^{+}$ & -0.021 & 0.059 & -0.027 & 0.475 & -0.260 & 0.005 & 0.037 & & \\
$\mathrm{CEC}^{+}$ & -0.252 & 0.008 & 0.425 & 0.191 & 0.139 & -0.614 & -0.111 & & \\
$\mathrm{Fe}_{2} \mathrm{O}_{3}$ & 0.134 & 0.124 & -0.360 & -0.497 & 0.143 & 0.237 & -0.107 & 1.000 & \\
$\mathrm{Al}_{2} \mathrm{O}_{3}$ & -0.035 & -0.118 & 0.184 & -0.063 & 0.240 & -0.047 & 0.105 & -0.136 & 1.000 \\
$\mathrm{PBS}^{+}$ & -0.043 & 0.287 & -0.224 & 0.246 & -0.426 & 0.160 & 0.139 & 0.166 & -0.360 \\
\hline
\end{tabular}

\begin{tabular}{lcccccc|c|c|c|}
\hline & $\mathrm{N}$ & $\mathrm{P}_{2} \mathrm{O}_{5}$ & $\mathrm{~K}_{2} \mathrm{O}$ & $\mathrm{Ca}^{++}$ & $\mathrm{Mg}^{++}$ & $\mathrm{K}^{+}$ & $\mathrm{Na}^{+}$ & $\mathrm{CEC}$ \\
\hline $\mathrm{N}$ & 1.000 & & & & & & & \\
$\mathrm{P}_{2} \mathrm{O}_{5}$ & 0.485 & 1.000 & & & & & & \\
$\mathrm{~K}_{2} \mathrm{O}$ & 0.523 & 0.483 & 1.000 & & & & & \\
$\mathrm{Ca}^{++}$ & 0.521 & 0.453 & 0.188 & 1.000 & & & & \\
$\mathrm{Mg}^{++}$ & 0.228 & 0.102 & 0.059 & 0.168 & 1.000 & & & \\
$\mathrm{~K}^{+}$ & 0.490 & 0.058 & 0.170 & 0.210 & 0.424 & 1.000 & & \\
$\mathrm{Na}^{+}$ & 0.362 & 0.318 & 0.792 & 0.083 & 0.051 & 0.233 & 1.000 & \\
$\mathrm{CEC}^{+}$ & 0.490 & 0.058 & 0.170 & 0.209 & 0.424 & 1.000 & 0.233 & 1.000 \\
$\mathrm{Fe}_{2} \mathrm{O}_{3}$ & -0.521 & -0.201 & -0.432 & -0.191 & 0.091 & -0.291 & -0.490 & -0.291 \\
$\mathrm{Al}_{2} \mathrm{O}_{3}$ & 0.321 & -0.188 & 0.004 & 0.003 & -0.235 & 0.156 & -0.129 & 0.156 \\
$\mathrm{PBS}$ & -0.009 & 0.395 & 0.202 & 0.339 & 0.256 & -0.622 & 0.055 & -0.622 \\
\hline
\end{tabular}


Table.6 Microbial biomass carbon (MBC) in soils of Ri-Bhoi district

\begin{tabular}{|c|c|c|c|c|}
\hline \multirow{2}{*}{ Horizon } & \multirow{2}{*}{ Depth (cm) } & \multicolumn{3}{|c|}{ Microbial Biomass Carbon $(\boldsymbol{\mu g} / \mathbf{g})$} \\
\cline { 3 - 5 } & & Pre-monsoon & Monsoon & Post-monsoon \\
\hline B1: Mynsain (Agril crop) & & & & \\
Ap & $0-20$ & 479.21 & 582.79 & 365.02 \\
Bw1 & $20-35$ & 391.46 & 432.97 & 315.52 \\
Bw2 & $35-60$ & 216.49 & 348.81 & 254.08 \\
Bw3 & $60-75$ & 178.33 & 349.53 & 290.72 \\
C & $75-150$ & 199.29 & 208.18 & 257.06 \\
B2 : Umeit (Horticulture farm) & & & & \\
Ap & $0-15$ & 445.00 & 626.79 & 517.10 \\
AB & $15-35$ & 254.00 & 439.67 & 377.53 \\
Bw1 & $35-85$ & 147.08 & 587.82 & 279.34 \\
Bw2 & $85-120$ & 105.61 & 562.17 & 165.71 \\
C & $120-180$ & 119.97 & 421.05 & 223.36 \\
A & & & & \\
Bw1 & $0-20$ & 520.18 & 646.57 & 452.03 \\
Bw2 & $20-45$ & 348.86 & 375.00 & 217.66 \\
Bw3 & $45-85$ & 142.92 & 413.02 & 218.02 \\
C & $85-115$ & 195.47 & 221.68 & 197.39 \\
& $115-160$ & 156.84 & 193.21 & 256.37 \\
\hline
\end{tabular}

Table.7 Correlation coefficients (r) among Microbial Biomass Carbon (MBC) and soil properties

\begin{tabular}{|c|c|c|c|c|c|c|c|c|c|}
\hline & Sand & Silt & Clay & $\mathrm{OC}$ & $\mathrm{BD}$ & $\mathrm{pH}$ & $\mathrm{EC}$ & $\mathrm{Fe}_{2} \mathrm{O}_{3}$ & $\mathrm{Al}_{2} \mathrm{O}_{3}$ \\
\hline $\begin{array}{c}\text { MBC } \\
\text { Pre-mosoon }\end{array}$ & 0.008 & 0.092 & -0.109 & 0.871 & -0.726 & 0.019 & 0.006 & -0.316 & -0.2 \\
\hline $\begin{array}{c}\text { MBC } \\
\text { Monsoon }\end{array}$ & -0.231 & 0.153 & 0.238 & 0.664 & -0.405 & -0.054 & -0.272 & -0.096 & -0.284 \\
\hline $\begin{array}{c}\text { MBC } \\
\text { Post-monsoon }\end{array}$ & -0.094 & 0.035 & 0.126 & 0.507 & -0.384 & -0.270 & -0.074 & 0.007 & -0.009 \\
\hline
\end{tabular}

\begin{tabular}{|c|c|c|c|c|c|c|c|c|c|}
\hline & $\mathrm{N}$ & $\mathrm{P}_{2} \mathrm{O}_{5}$ & $\mathrm{~K}_{2} \mathrm{O}$ & $\mathrm{Ca}^{++}$ & $\mathrm{Mg}^{++}$ & $\mathrm{K}^{+}$ & $\mathrm{Na}^{+}$ & CEC & PBS \\
\hline $\begin{array}{c}\text { MBC } \\
\text { Pre-mosoon }\end{array}$ & 0.355 & 0.723 & 0.544 & 0.523 & 0.087 & -0.067 & 0.368 & -0.067 & 0.504 \\
\hline $\begin{array}{c}\text { MBC } \\
\text { Monsoon }\end{array}$ & 0.285 & 0.631 & 0.173 & 0.482 & 0.101 & 0.211 & 0.195 & 0.211 & 0.145 \\
\hline $\begin{array}{c}\text { MBC } \\
\text { Post-monsoon }\end{array}$ & 0.218 & 0.365 & -0.023 & 0.364 & 0.406 & 0.151 & -0.225 & 0.151 & 0.246 \\
\hline
\end{tabular}


Fig.1

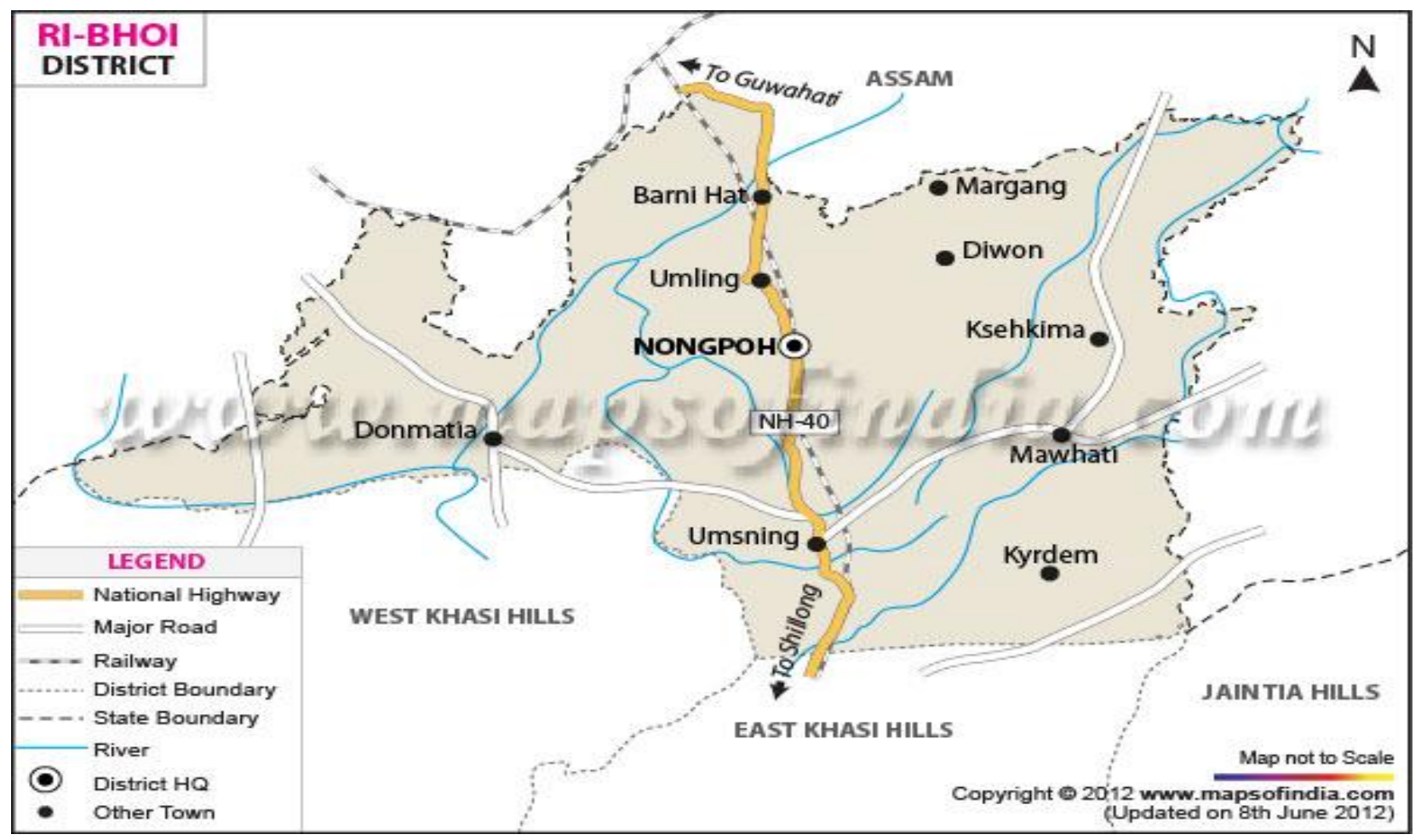

Fig.2 Season-wise Soil Microbial Biomass carbon in the surface horizons of Ri-Bhoi district

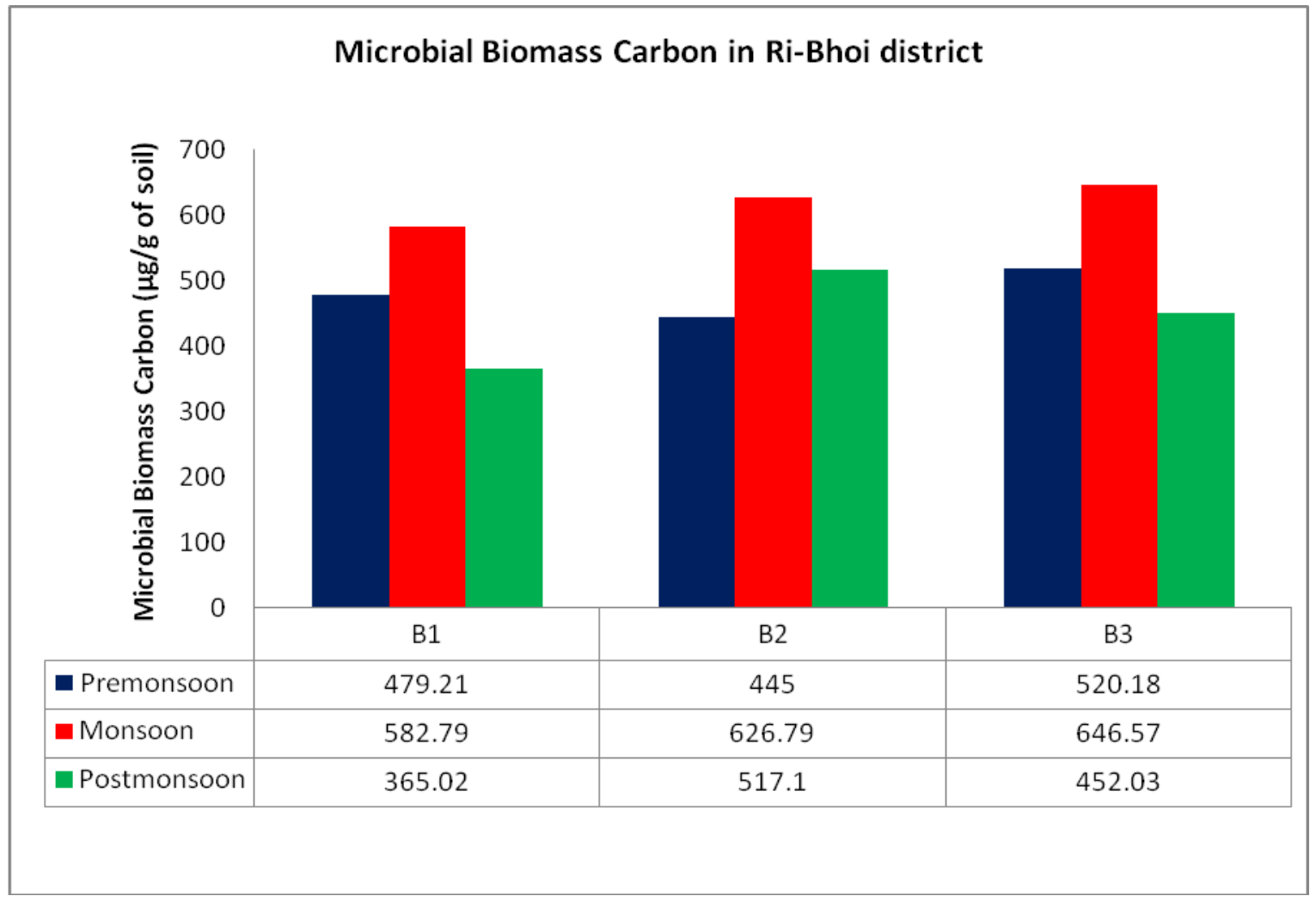


Significant positive correlation between MBC and available $\mathrm{N}, \mathrm{P}_{2} \mathrm{O}_{5}$ and exchangeable $\mathrm{Ca}^{++}$ (Table 7) suggests that microbial biomass carbon is a good source of these nutrients in the soil. Goyal et al., (1992) also observed that the increase and decrease in MBC could be easily related with mineral $\mathrm{N}$ pool of the soils. Results from the present study demonstrate that management certain types of vegetation and land use exert a profound influence on microbial biomass C. Different plant species affect soil microbial processes, which are dependent upon their litter quality and quantity and also upon below-ground biomass supporting microbial activities. The climatic conditions in the different season of the year changes the soil dynamics and thus resulting to a variation in $\mathrm{MBC}$ in different land uses. Our data suggest that forest soil may be healthier when compared to other land use soils. Results also indicate that microbial biomass $\mathrm{C}$ was influenced by physic-chemical characteristics of the soil at the study sites.

\section{Acknowledgement}

The author is thankful to the Department of Soil Science and Agronomy, Assam Agricultural University, Jorhat, Assam for their guidance and support throughout the research programme.

\section{References}

Anderson, J.P.E. and K.H. Domsch. 1989. Ratios of microbial biomass carbon to total organic carbon in arable soils. Soil Biol. Biochem. 21: 471-479.

Azam, F., S. Farooq and A. Lodhi 2003. Microbial biomass in agricultural soilsdetermination, synthesis, dynamics and role in plant nutrition. Pakistan J. Biol. Sci. 6: 629-639.

Bezdicek, D.F., R.I. Papendick and R. Lal. 1996. Introduction: importance of soil quality to health and sustainable land management. In: Methods of Assessing
Soil Quality (Eds.: J.W. Doran and A.J. Jones). SSSA Spec. Publ. 49, Madison, pp. $1-18$.

Black, G. R. (1965). Bulk density. In: Black, C. A. (ed) Methods of Soil Analysis, part 1, American Society of Agronomy.

Bray, R. H. and Kurtz, L. T. (1945). Determination of total organic and available phosphate in soils. Soil Sci. 59: 39-45.

Carter, M.R., 1986. Microbial biomass and mineralizable nitrogen in Solonetzic soils: Influence of gypsum and lime amendments. Soil Biol. Biochem., 18: 531-537.

Diaz-Ravina, M., Acea, M.J. and Carballas, T., 1995. Seasonal changes in microbial biomass and nutrient flush in forest soils. Biol. Fertil. Soils, 19: 220-226.

Diaz-Ravina, M., Carballas, T. and Acea, M.J., 1988. Microbial biomass and metabolic activity in four acid soils. Soil Biol. Biochem., 20: 817-823.

Franzluebbers, A.J., F.M. Hons and D.A. Zuberer. 1995. Soil organic carbon, microbial biomass, and mineralizable carbon and nitrogen in sorghum. Soil Sci. Soc. Am. J. 59: 460-466.

Franzluebbers, A.J., R.L. Haney and F.M. Hons. 1999. Relationships of chloroform fumigation-incubation to soil organic matter pools. Soil Biol. Biochem. 31: 395405.

Gestel, M.V., Merckx, R. and Vlassak, K., 1993. Microbial biomass and activity in soils with fluctuating water contents. Geoderma, 56: 617-626.

Goyal, S., Mishra, M. M., Hooda, I. S. and Raghubir, S. (1992). Organic matter, microbial biomass relationship in field experiments under tropical conditions Effect of inorganic fertilization and organic amendments. Soil Biol. Biochem. 24: 10811084.

Gregorich, E.G., B.C. Liang, C.F. Drury, A.F. Mackenzie and W.B. McGill. 2000. Elucidation of the source and turnover of water soluble and microbial biomass carbon in agricultural soils. Soil Biol. Biochem. 32: 581-587. 
Haney, R.L., A.J. Franzluebbers, F.M. Hons, L.R. Hossner and D.A. Zuberer. 2001. Molar concentration of $\mathrm{K} 2 \mathrm{SO} 4$ and soil $\mathrm{pH}$ effect estimation of extractable $\mathrm{C}$ with chloroform fumigation extraction. Soil Biol. Biochem. 33: 1501-1507.

Jackson, M. L. (1973). Soil Chemical Analysis. Prentice Hall of India Pvt. Ltd., New Delhi.

Jenkinson, D. S. and Ladd, J. N. (1989). Microbial biomass in soil: Measurement and turn over. In: Soil Biochemistry. Paul, E. A. and Ladd, J. N. (ed.). Dekker, New York, USA.

Kaiser, E.A., Muller, T., Roergensen, R.G., Insam, H. and Heinemeyer, O., 1992. Evaluation of methods to estimate the soil microbial biomass and the relationship with soil texture and organic matter. Soil Biol. Biochem., 24: 675-683.

Maithani, K.; Tripathi, R.S.; Arunachalam, A. and Pandey, H. N. (1996). Seasonal dynamics of microbial biomass $\mathrm{C}, \mathrm{N}$ and $\mathrm{P}$ during regrowth of a disturbed subtropical humid forest in north-east India, Applied Soil Ecology 4:31-37

Murrieta, V.M.S., B. Govaerts and L. Dendooven. 2007. Microbial biomass C measurements in soil of the central highlands of Mexico. Appl. Soil Ecol. 35: 432-440.

Nicojardot, B., Fauvet, G. and Cheneby, D., 1994. Carbon and nitrogen cycling through soil microbial biomass at various temperatures. Soil Biol. Biochem., 26: 253261.

Patra, D.D., Brookes, P.C., Coleman, J. and Jenkinson, D.S., 1990. Seasonal changes of soil microbial biomass in an arable land and a grassland soil which have been under uniform management for many years. Soil Biol. Biochem., 22: 739- 742.

Piper, C. S. (1966). Soil and plant analysis. The University of Adelaide, Australia.

Priha, O. 1999. Microbial activities in soils under Scots pine, Norway spruce and Silver birch. Research Papers 731, Finnish Forest Research Institute, Helsinki.

Ross, D.J., Tate, K.R., Cairns, A. and Meyrick, K.F., 1981. Fluctuations in microbial biomass indices at different sampling times from tussock grasslands. Soil Biol. Biochem., 13: 109- 114.

Sharma, P., S.C. Rai, R. Sharma and E. Sharma. 2004. Effects of landuse change on soil microbial $\mathrm{C}, \mathrm{N}$ and $\mathrm{P}$ in a Himalayan watershed. Pedobiologia 48: 83-92.

Singh, J.S., Raghuvanshi, A.S., Singh, R.S. and Srivastava, S.C., 1989. Microbial biomass acts as a source of plant nutrients in dry tropical forest and savanna. Nature, 399: 499-500.

Srivastava, S.C. and Singh, J.S., 1991. Microbial $\mathrm{C}, \mathrm{N}$ and $\mathrm{P}$ in dry tropical forest soils: Effects of alternate land-uses and nutrient flux. Soil Biol. Biochem., 23: 117124.

Subbiah, B.V. and Asija, G.L. (1956). A rapid procedure for the determination of available nitrogen in soils. Curr. Sci. 25: 259-260.

Vance, E. D.; Brookes, P. C. and Jenkinson, D. S. (1987). An extraction method for measuring soil microbial biomass C. Soil Biol. Biochem. 19: 703-707.

Walkley, A. and Black, L. R. (1934). An examination of Degtryreff method for determination of soil organic matter and a proposed modification of the chromic acid titration method. Soil Sci. 37: 29-38.

\section{How to cite this article:}

Euwanrida Adleen Shylla Lyngdoh and Karmakar, R.M. 2018. Seasonal Dynamics of Soil Microbial Biomass Carbon (SMBC) in Different Land Uses in Ri-Bhoi District of Meghalaya, India. Int.J.Curr.Microbiol.App.Sci. 7(03): 3737-3747.

doi: https://doi.org/10.20546/ijcmas.2018.703.432 